\title{
Overcoming Dormancy in Seeds of Amazonian Species
}

\author{
Gerson Dias da Silva Júnior ${ }^{1}$, Rubson da Costa Leite ${ }^{2}$, Guilherme Octávio de Sousa Soares ${ }^{2}$, \\ Tatiane de Sousa $\mathrm{Cruz}^{2}$, Robson da Costa Leite ${ }^{3}$, Amanda da Silva Reis ${ }^{3}$, José Lucas de Sousa Soares ${ }^{1}$ \\ \& Márcio Rogério Pereira Leite ${ }^{1}$ \\ ${ }^{1}$ Federal Institute of Education, Science and Technology of Tocantins, Araguatins, Tocantins, Brazil \\ ${ }^{2}$ Federal University of Tocantins, Araguaína, Tocantins, Brazil \\ ${ }^{3}$ Federal University of Tocantins, Gurupi, Tocantins, Brazil \\ Correspondence: Rubson da Costa Leite, Federal University of Tocantins, Araguaína, Tocantins, Brazil. Tel: \\ 55-63-999-579-410. E-mail: rubsonif@gmail.com
}

Received: March 12, 2018

doi:10.5539/jas.v10n6p245

\author{
Accepted: April 14, 2018 \\ Online Published: May 15, 2018 \\ URL: https://doi.org/10.5539/jas.v10n6p245
}

\begin{abstract}
Despite the importance of the Amazonian species Schizolobium amazonicum, there is still no official protocol to favor the germination process of its seeds. The objective of this study was to evaluate methods of overcoming dormancy of paricá seeds and the quality of seedlings produced. The work was carried out at the Federal Institute of Education, Science and Technology of Tocantins-Campus Araguatins. The experimental design was a completely randomized design with seven treatments and four replications. The treatments consisted of: intact seeds; lateral mechanical scarification of the tegument with electric emery for 2 seconds; lateral mechanical scarification of the tegument, using sandpaper number 50 for 1 minute + immersion in water at room temperature for 12 hours; chemical scarification of the tegument with caustic soda at $20 \%$ concentration for 30 minutes; chemical scarification of the tegument with caustic soda at a concentration of $20 \%$ for 45 minutes; immersion in water at $80^{\circ} \mathrm{C}+$ stay in water (room temperature) for 12 hours; immersion in water at $90{ }^{\circ} \mathrm{C}+$ stay in water (room temperature) for 12 hours. The treatment with lateral mechanical scarification of the integument using electric emery for 2 seconds is the most suitable for overcoming dormancy in paricá seeds. Methods of overcoming dormancy had no influence on the quality of paricá seedlings.
\end{abstract}

Keywords: mechanical scarification, Paricá, Schizolobium amazonicum

\section{Introduction}

Currently planted forests represent $7 \%$ of the world's forests, and in Brazil this activity will gain more importance due to commitments to reduce greenhouse gases and conservation of native forests, thus encouraging commercial plantations (IBÁ, 2015; Soares et al., 2017).

In the Amazon region, there are several native species with potential for use in reforestation and for the purpose of commercial plantations (DIAS et al., 2015), among them the specie Schizolobium amazonicum Huber ex Ducke (Paricá) has been gaining notoriety at the national level as a promising specie, with great acceptance in the national and foreign markets due to its silvicultural potential (Vidaurre et al., 2012; Dias et al., 2015).

In Brazil, there are around 90,047 hectares with paricá plantations, considering the states of Pará, Maranhão and Tocantins (IBÁ, 2016). Currently there is a growing interest in the cultivation of this species due to its good volumetric performance mainly in agroforestry systems (Cordeiro et al., 2015), with average productivity like Pinus species (around 20 to $30 \mathrm{~m}^{3} /$ ha/year) and superior to teak with 15 to $20 \mathrm{~m}^{3} /$ ha/year (Iwakiri et al., 2010).

Despite the great silvicultural value, paricá seeds present a type of dormancy very common in legumes, which is the impermeability of the tegument to the entrance of water, which hinders the production of seedlings of this species (Cruz \& Pereira, 2014). Silva Neto et al. (2007), reinforce that seeds of tropical legumes present impermeability of the integument, being able to reach up to $98 \%$ of the seeds.

When harvested before the fruiting process (dehiscence) the seeds of paricá present higher germination, but due to their high moisture content, they present high levels of infestation by microorganisms. However, when harvested after the dispersal process, they have good germination levels only after 6 years (Cruz \& Pereira, 2014; Dapont et al., 2014). 
Dapont et al. (2014), report that despite the importance of the species Schizolobium amazonicum, there is not still an official protocol to favor the germination process of its seeds.

Considering the dormancy of paricá seeds, together with the silvicultural potential of the species, research aimed at determining efficient methods to overcome dormancy of seeds is of fundamental importance, favoring the production of seedlings of the species. For this reason, the objective was to evaluate methods of overcoming dormancy of paricá seeds and the quality of seedlings produced.

\section{Material and Methods}

The work was carried out in the Federal Institute of Education, Science and Technology of Tocantins-Campus Araguatins, in coordinates UTM: 824304.76 and 9374641.48. The seeds of Paricá (S. amazonicum) used in the experiment were provided by a company specialized in the seed trade. The experiment started in September 2016 under greenhouse conditions.

The methods of overcoming the dormancy used were: Intact seeds (T1); Lateral mechanical scarification of the integument with electric emery for two seconds (T2); Lateral mechanical scarification of the integument, using sandpaper $\mathrm{n}^{\circ} 50$ for one minute + immersion in water at room temperature for twelve hours (T3); Chemical scarification of the integument with caustic soda at a concentration of $20 \%$ for thirty minutes (T4); Chemical scarification of the integument with caustic soda at a concentration of $20 \%$ for forty-five minutes (T5); Immersion in water at $80^{\circ} \mathrm{C}+$ permanence in water (room temperature) for twelve hours (T6); Immersion in water at $90{ }^{\circ} \mathrm{C}+$ stay in water (room temperature) for 12 hours (T7).

After submission to the respective treatments, the seeds (sanitized in $2 \%$ sodium hypochlorite solution for one minute) were sown two centimeters deep in polyethylene trays, filled with washed sand substrate and previously sterilized in a forced circulation oven $\left(200{ }^{\circ} \mathrm{C}, 2 \mathrm{~h}\right)$. The substrate sterilization process and the number of seeds used per replicate in each treatment considered the guidelines contained in the Rules for Seed Analysis (MAPA, 2009).

The experimental design was completely randomized, with seven treatments and four replicates, each plot consisting of a polyethylene tray containing 25 seeds. The trays used in the experiment had dimensions of $60 \mathrm{~cm}$ $\times 37 \mathrm{~cm} \times 15 \mathrm{~cm}$ and contained about $28 \mathrm{~kg}$ of washed sand. After sowing, the trays were kept in a room with controlled temperature $\left( \pm 30^{\circ} \mathrm{C}\right)$ in the presence of constant light. Irrigations were performed on alternate days to maintain substrate moisture at optimal levels for germination. All the water used for wetting the substrate was previously submitted to the distillation process.

The variables evaluated: emergence of seedlings at 7 days (ES7); emergence of seedlings at 21 days (ES21); emergency speed index (ESI); relative emergency frequency (REF); percentage of normal seedlings (PNS); dry matter of the aerial part and roots of seedlings (DMAP and DMR).

The EPS corresponded to the percentage of seedlings emerged until the 7th day after sowing. The ES21 corresponded to the percentage of emergent plants up to 21 days after sowing. ESI was determined according to Maguire (1962), based on the following equation:

$$
\mathrm{ESI}=(\mathrm{E} 1 / \mathrm{N} 1)+(\mathrm{E} 2 / \mathrm{N} 2)+\ldots+(\mathrm{En} / \mathrm{Nn})
$$

Where, E1, E2, .. En = number of seedlings emerged each day; N1, N2, .. Nn = number of days after sowing from the first to the last count.

For REF, counting the number of seedlings that emerged per day, until the last evaluation (Labouriau \& Valadares, 1976), the values being expressed as a percentage. For the PNS, those seedlings that showed potential to continue their development and to give rise to normal plants, without injuries caused by the methods of overcoming dormancy were verified, being the result expressed in percentage.

After the emergency test, the seedlings were removed from the trays, the material being separated by repetition according to each treatment, and then taken to the seed laboratory to evaluate the quality of seedlings.

The aerial part and roots of the seedlings were considered normal, with the aid of a pair of scissors, making the cut in the region of the collection. Then they were weighed in scales. Subsequently these samples were submitted to oven drying with forced air circulation, regulated at $80{ }^{\circ} \mathrm{C}$ for 24 hours (Nakagawa, 1999), soon after they were weighed to obtain the DMAP and DMR.

All data were evaluated for normality by the Shapiro-Wilk method and when necessary transforms $(x=$ square root $(\mathrm{x}))$. Subsequently performed the analysis of variance, with significance measured by the $\mathrm{F}$ test $(\mathrm{p} \leq 0.05)$. To compare the means, the SNK test was used $(\mathrm{p} \leq 0.01)$. 


\section{Results and Discussion}

The results of the analysis of variance indicated a significant effect among treatments by the $\mathrm{F}$ test for the variables ES7, ES21, ESI and PNS. As for the variables that evaluated the quality of DMAP and DMR seedlings was not significant in function of applied treatments. Figure 1 shows the means of emergence of seedlings at seven days after sowing (DAS), to 21 DAS and the emergency speed index.
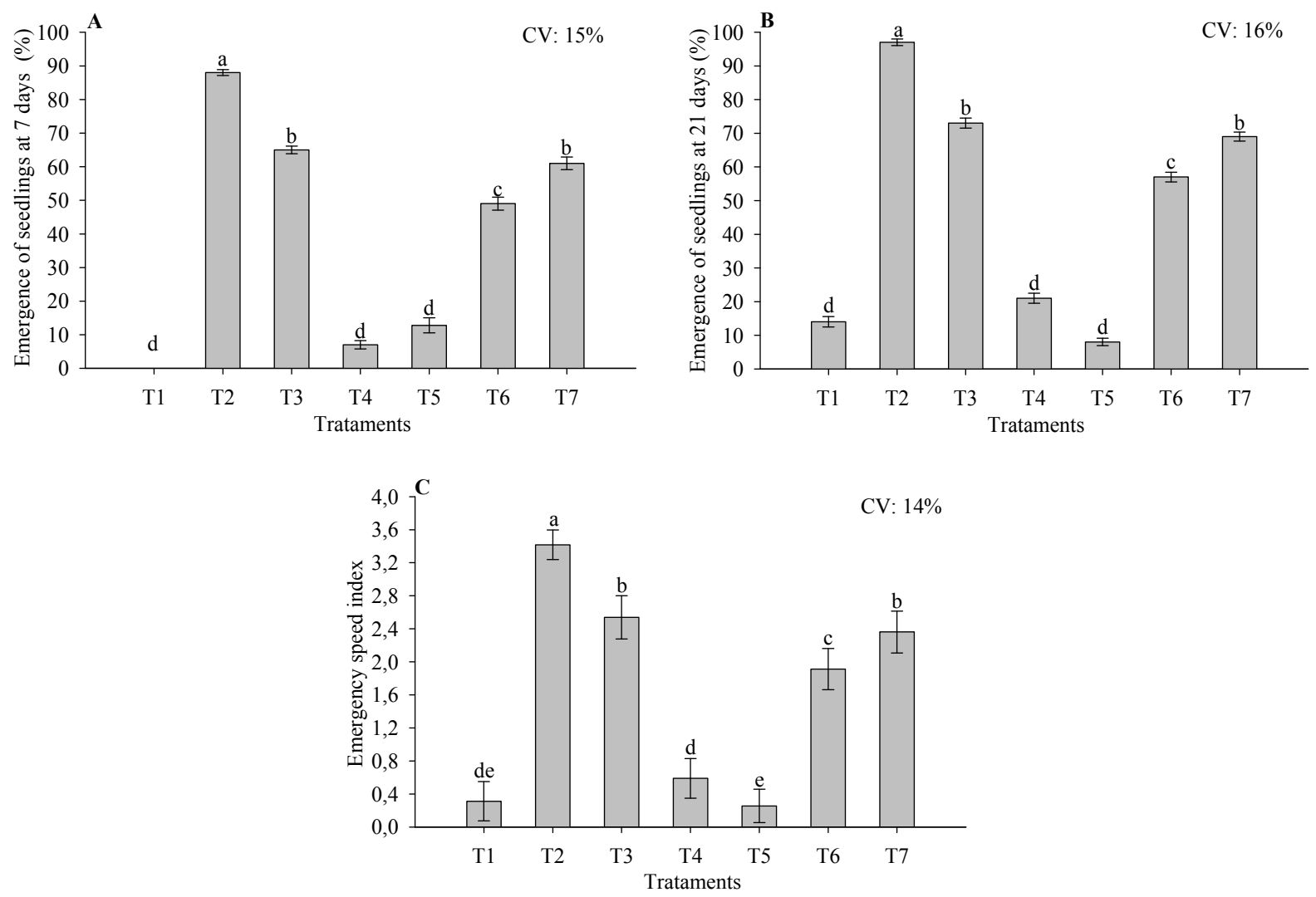

Figure 1. Emergence of seedlings at 7 days (A), emergence of seedlings at 21 days (B) and emergency speed index $(\mathrm{C})$ of the paricá seeds, undergoing treatments to overcoming dormancy

Note. Means followed by the same letter do not differ significantly by the SNK test $(\mathrm{p}<0.01)$; Intact seeds (T1); Lateral mechanical scarification of the integument with electric emery for two seconds (T2); Lateral mechanical scarification of the integument, using sandpaper $\mathrm{n}^{\circ} 50$ for one minute + immersion in water at room temperature for twelve hours (T3); Chemical scarification of the integument with caustic soda at a concentration of $20 \%$ for thirty minutes (T4); Chemical scarification of the integument with caustic soda at a concentration of $20 \%$ for forty-five minutes (T5); Immersion in water at $80{ }^{\circ} \mathrm{C}+$ permanence in water (room temperature) for twelve hours (T6); Immersion in water at $90^{\circ} \mathrm{C}+$ stay in water (room temperature) for 12 hours (T7).

For the variables ES7 and ES21 it was verified that the treatment with lateral mechanical scarification of the integument using electric emery for 2 seconds, presented higher percentage of emerged seedlings, differing from the other treatments to overcome dormancy, followed by mechanical scarification with sandpaper for one minute plus immersion in water and treatment with immersion in water at $90{ }^{\circ} \mathrm{C}$ plus permanence in water at room temperature at 7 and 21 DAS.

Comparing the emergency behavior in the treatments during the two evaluated periods (7 and 21 DAS), it was observed that even over time the efficiency of one treatment in relation to the others did not vary, an evaluation at seven days after sowing was enough to determine the most efficient method to overcome dormancy in paricá seeds. 
The lateral opening of the tegument with electric emery, may have promoted greater water intake and, thus promoting the greater emergence of seedlings. Corroborating with Cruz and Pereira (2014), they mention that paricá seeds present dormancy due to the difficulty of imbibing the seed.

Silva-Neto et al. (2007), cited that in seeds of tropical legumes the impermeability of the integument to water is the most common mechanism of dormancy. Now Hartmann et al. (1996) say that in species where dormancy is due to impermeability of the tegument to water, mechanical scarification is the most commonly used method.

About the mechanical scarification treatment with sandpaper for one minute plus immersion in water, although it presents itself as the second most efficient method, together with the immersion treatment in water at $90{ }^{\circ} \mathrm{C}$ and immersion in water at room temperature, a high rate of contamination of the seeds by fungal attack was observed. This fact may have underestimated the potential for dormancy overcoming this method.

Possibly a major stria in the seed, performed by scarification, favored the incidence of microorganisms that deteriorated a considerable number of seeds and could have interrupted the germination process. Mohamed-Yasseen et al. (1994), mention that although the existence of impermeable integument is an undesirable characteristic of the seedling emergence, it is also recognized for protecting the seed from temperature fluctuations humidity and the incidence of microorganisms.

Another plausible justification for the considerable infestation of the seeds by fungi in the mechanical scarification treatment with sandpaper for one minute plus immersion in water, is since only the process of boiling the water used for immersion of the seeds after scarification, has not been efficient in elimination of microorganisms.

The treatments with chemical scarification with caustic soda for thirty minutes and chemical scarification with caustic soda for forty-five minutes did not differ statistically from the control treatment, requiring time and labor without any increase in seedling emergence.

The necessity of methods of overcoming and dormancy in seeds of $S$. amazonicum becomes evident when the results of the control treatment, where the percentage of seedlings emerged was 0 and $14 \%$, respectively for 7 and 21 DAS. This low percentage found at the end of the experiment in this treatment is reinforced by Cruz and Pereira (2014), which mention the fact that non-scarified seeds present slow and uneven germination and reach high percentages only after 6 years.

About ESI, when the treatment with lateral mechanical scarification of the tegument with electric emery for two seconds, differed statistically from the other treatments, presenting 3.4 of the ESI, followed by treatments with mechanical scarification and immersion in water and immersion in water at $90{ }^{\circ} \mathrm{C}$ plus immersion in water at room temperature with ESI of 2.5 and 2.3, respectively.

During mechanical chiseling with electric emery for two seconds, the maintenance of the integument pressed against the emery caused a considerable heating in the seed due to the friction, which may have removed or diminished the amount of waterproofing waxes present in the tegument, as cited by Ferreira and Borghetti (2004), thus favoring a higher ESI.

Treatment with chemical scarification with caustic soda for forty-five minutes, presented the lowest ESI value (0.2), being like the control treatment, soon this treatment did not configure as an alternative for ESI increase in S. amazonicum seeds. Treatment with caustic soda for thirty minutes, despite an ESI superior to the treatment with caustic soda for forty-five minutes, did not differ statistically from the control treatment. The treatment with immersion in water at $80{ }^{\circ} \mathrm{C}$ and immersion in water at room temperature presented an intermediate value for ESI (1.91).

The values of ESI, for the treatments with caustic soda resemble those obtained by Dapont et al. (2014), which obtained averages of ESI statistically equal to that of the control treatment in all the treatments that consisted of immersion of the seeds in concentrated solution of sulfuric acid, even in different periods of imbibition, ranging from 5 to 50 minutes.

The Figure 2 demonstrates the emergence behavior of seedlings of $S$. amazonicum from seeds submitted to different methods to overcome dormancy, evaluated from the 7 to the 21 days after sowing. 


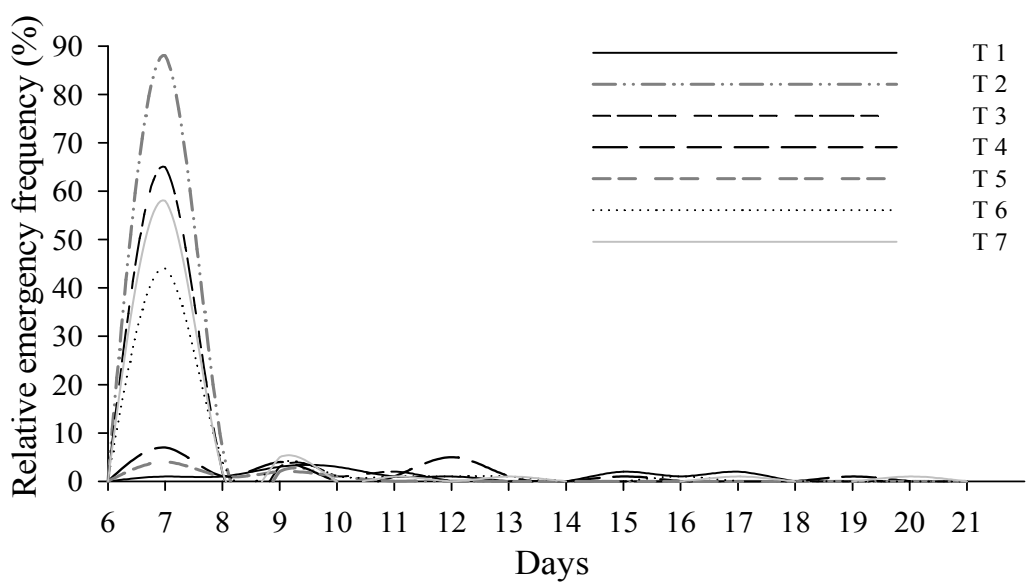

Figure 2. relative emergency frequency (REF) due to methods of overcoming dormancy in paricá seeds

Note. Intact seeds (T1); Lateral mechanical scarification of the integument with electric emery for two seconds (T2); Lateral mechanical scarification of the integument, using sandpaper $\mathrm{n}^{\circ} 50$ for one minute + immersion in water at room temperature for twelve hours (T3); Chemical scarification of the integument with caustic soda at a concentration of $20 \%$ for thirty minutes (T4); Chemical scarification of the integument with caustic soda at a concentration of $20 \%$ for forty-five minutes (T5); Immersion in water at $80{ }^{\circ} \mathrm{C}+$ permanence in water (room temperature) for twelve hours (T6); Immersion in water at $90{ }^{\circ} \mathrm{C}+$ stay in water (room temperature) for 12 hours (T7).

Analyzing the figure, the period of greatest emergence of seedlings for most treatments was concentrated between 7 and 12 days after sowing. It should be noted once again that the treatment with electric emery scarification for two seconds stood out from the others, with $88 \%$ of its seeds emerged at 7 days after sowing.

The treatments with the use of caustic soda and the control treatment besides presenting low percentages of germination at the end of the experiment (22.8 and 14.0\%) presented high fluctuation in the REF, demonstrating that the emergence of these seedlings did not occur uniformly. This behavior would harm the plant stand in a nursery producing seedlings, because the uniformity of emergence of seedlings is directly linked to the standardization of the seedlings that will be taken to the field.

For the percentage of normal seedlings, it was observed that the treatment with caustic soda for thirty minutes presented a lower value in relation to the other treatments (Figure 3), with $43 \%$ of normal seedlings.

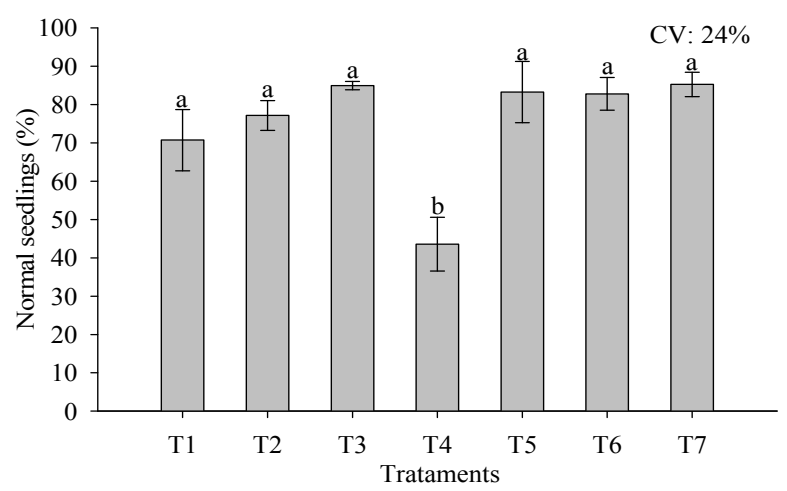

Figure 3. Percentage of normal seedlings from dormancy overcoming treatments

Note. Means followed by the same letter do not differ significantly by the SNK test $(\mathrm{p}<0.01)$; Intact seeds (T1); Lateral mechanical scarification of the integument with electric emery for two seconds (T2); Lateral mechanical scarification of the integument, using sandpaper $\mathrm{n}{ }^{\circ} 50$ for one minute + immersion in water at room temperature for twelve hours (T3); Chemical scarification of the integument with caustic soda at a concentration of $20 \%$ for thirty minutes (T4); Chemical scarification of the integument with caustic soda at a concentration of $20 \%$ for forty-five minutes (T5); Immersion in water at $80{ }^{\circ} \mathrm{C}+$ permanence in water (room temperature) for twelve hours (T6); Immersion in water at $90^{\circ} \mathrm{C}+$ stay in water (room temperature) for 12 hours (T7). 
Although the low value of normal seedlings found in the treatment with the use of caustic soda for thirty minutes, it is difficult to attribute this response to the applied treatment, because the treatment with caustic soda in the same concentration and for a longer time (forty-five minutes) did not present similar values. This fact may have occurred due to the low percentage of seedlings emerged in some treatments, therefore a low number of total seedlings and consequently a high representativity of any abnormal plant found.

Factors related to paricá seed hardness, as quoted by some authors (Borges et al., 2004; Souza, 2006), may have contributed to the high number of abnormal seedlings obtained in the treatments, being aggravated in the treatment with caustic soda for thirty minutes, since the integument presented itself as a physical barrier to the perfect development of the embryo.

The main abnormality found in S. amazonicum seedlings at the end of the experimental period, in all treatments, was related to the difficulty that the seedling obtained in getting rid of the integument that enveloped the embryo, before beginning the germination, resulting in unviable seedlings being used in the formation of the species' crops and, consequently, causing economic losses.

Regarding DMAP and DMR in S. amazonicum seedlings evaluated at 21 DAS, there was no difference between the methods of overcoming dormancy used (Figure 4). It showed that none of the evaluated treatments affected these variables.
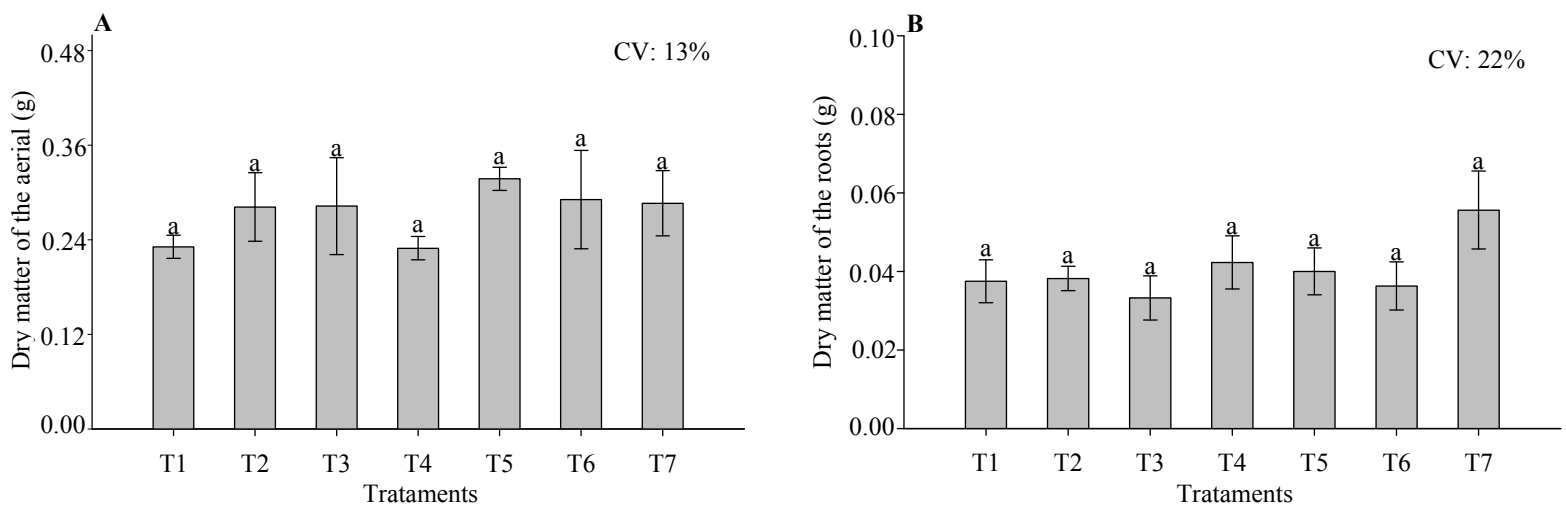

Figure 4. Dry matter of the aerial part (A) and Dry matter of the roots (B) of seedlings of paricá from treatments to overcoming dormancy at 21 days after sowing

Note. Means followed by the same letter do not differ significantly by the SNK test $(\mathrm{p}<0.01)$; Intact seeds (T1); Lateral mechanical scarification of the integument with electric emery for two seconds (T2); Lateral mechanical scarification of the integument, using sandpaper $\mathrm{n}^{\circ} 50$ for one minute + immersion in water at room temperature for twelve hours (T3); Chemical scarification of the integument with caustic soda at a concentration of $20 \%$ for thirty minutes (T4); Chemical scarification of the integument with caustic soda at a concentration of $20 \%$ for forty-five minutes (T5); Immersion in water at $80{ }^{\circ} \mathrm{C}+$ permanence in water (room temperature) for twelve hours (T6); Immersion in water at $90^{\circ} \mathrm{C}+$ stay in water (room temperature) for 12 hours (T7).

According Krzyzanowski et al. (1999), one way to analyze the vigor of the seeds with some accuracy is to determine the transfer of dry mass from the reserve tissues to the embryonic axis, through the weight of the dry mass of the seedling.

For Gomes and Paiva (2006), the weight of the aerial part has a direct correlation with the survival and initial performance of the seedlings after planting, being an indicator of rusticity of plants and the dry matter of the root is related to a greater root development which becomes beneficial for the growth of the seedlings in the field. Therefore, the results for seedling quality demonstrate that the methods of overcoming dormancy do not affect the quality of the emerged normal seedlings.

\section{Conclusions}

The treatment with lateral mechanical scarification of the integument using electric emery for 2 seconds is the most suitable for overcoming dormancy in paricá seeds, also the one that presents greater uniformity of emergence of seedlings. 
Chemical treatment of paricá seeds with caustic soda did not promote greater emergence and provoked insults to seedlings that emerged.

Methods of overcoming dormancy had no influence on the quality of paricá seedlings.

\section{References}

Araújo, E. F., Aguiar, A. S., Arauco, A. M. S., Gonçalves, E. O., \& Almeida, K. N. S. (2017). Crescimento e qualidade de mudas de paricá produzidas em substratos à base de resíduos orgânicos. Nativa, 5(1), 16-23. https://doi.org/10.5935/2318-7670.v05n01a03

Borges, E. E. L., Ribeiro, J. I., Rezende, S. T., \& Perez, S. C. J. G. A. (2004). Alterações fisiológicas em sementes de Tachigalia multijuga (Benth.) (Mamoneira) relacionadas aos métodos para a superação da dormência. Revista Árvore, 28, 317-325. https://doi.org/10.1590/S0100-67622004000300001

Cordeiro, I. M. C. C., Barros, P. L. C., Lameira, O. A., \& Gazel Filho, A. B. (2015). Avaliação de plantios de paricá (Schizolobium parahyba var. amazonicum (Huber ex Ducke) de diferentes idades e sistemas de cultivo no município de Aurora do Pará-PA (Brasil). Revista Ciência Florestal, 25(3), 679-687. https://doi.org/10.5902/1980509819618

Cruz, E. D., \& Pereira, A. G. (2014). Germinação de Sementes de Espécies Amazônicas: Paricá [Schizolobium parahyba var. amazonicum (Huber ex Ducke) Barneby] (Comunicado Técnico 251). Belém, PA.

Dapont, E. C., Silva, J. B., Oliveira, J. D., Alves, C. Z., \& Dutra, A. S. (2014). Métodos para acelerar e uniformizar a emergência de plântulas de Schizolobium amazonicum. Revista Ciência Agronômica, 45(3), 598-605. https://doi.org/10.1590/S1806-66902014000300022

Dias, P. C., Ataíde, G. M., Xavier, A., Oliveira, L. S., \& Paiva, H. N. (2015). Propagação vegetativa de Schizolobium amazonicum por estaquia. CERNE, 21(3), 379-386. https://doi.org/10.1590/01047760201 521031467

Feitosa, A. A. N., Negreiros, J. M., Nascimento, G. S., Ferreira, J. B., \& Oliveira, S. S. (2015). Superação de dormência em sementes de Schizolobium amazonicum Ducke. Enciclopédia Biosfera, 11(2), 154-166.

Ferreira, A. G., \& Borghetti, F. (2004). Germinação: do básico ao aplicado (p. 136). Porto Alegre: Artmed.

Gomes, J. M., \& Paiva, H. N. (2006). Viveiros Florestais: propagação sexuada (1st ed., p. 45) Viçosa: UFV.

Hartmann, H. T., Kester, D. E., Davies Junior, F. T., \& Geneve, R. L. (1996). Plant propagation: Principles and practices (6th ed., p. 770) New Jersey: Simom \& Schuster.

IBÁ (Indústria Brasileira de Árvores). Relatório IBÁ 2016/ano base 2015. Retrieved from http://www.florestal. gov.br/snif/recursos-florestais/asflorestas-plantadas

Iwakiri, S., Zeller, F., Pinto, J. A., Ramirez, M. G. L., Souza, M. M., \& Seixas, R. (2010). Avaliação do potencial de utilização da madeira de Schizolobium amazonicum "Paricá" e Cecropia hololeuca "Embaúba" para produção de painéis aglomerados. Acta Amazônica, 40(2), 303-308. https://doi.org/10.1590/S0044-5967 2010000200008

Krzyzanowski, F. C., Vieira, R. D., \& França Neto, J. B. (1999). Vigor de sementes: Conceitos e testes (p. 218). Londrina: ABRATES.

Labouriau, L. G., \& Valadares, M. E. B. (1976). On the germination of seeds Calotropis procera (Ait.). Anais da Academia Brasileira de Ciências, 48(2), 263-284.

Maguire, J. D. (1962). Velocidade de germinação na seleção e avaliação da emergência e vigor das plântulas. Revista Ciência da Colheita, 2(1), 176-177.

MAPA (Ministério da Agricultura, Pecuária e Abastecimento). (2009). Regras para análise de sementes (p. 399). Secretaria de Defesa Agropecuária, Brasília: Mapa/ACS.

Mohamed-Yasseen, Y., Barringer, S. A., Splittstoesser, W. E., \& Costanza, S. (1994). O papel das camadas de sementes na viabilidade das sementes. Revisão Botânica, 60, 426-439.

Nakagawa, J. (1999). Testes de vigor baseados no desempenho das plântulas. In F. C. Krzyzanoski, R. D. Vieira, \& J. B. França Neto (Eds.), Vigor de sementes: Conceitos e testes (p. 21). ABRATES.

Schwartz, G., Pereira, P. C. G., Siviero, M. A., Pereira, J. F., Ruschel, A. R., \& Yared, J. A. G. (2017). Enrichment planting in logging gaps with Schizolobium parahyba var. amazonicum (Huber ex Ducke) 
Barneby: A financially profitable alternative for degraded tropical forests in the Amazon. Forest Ecology and Management, 390, 166-172. https://doi.org/10.1016/j.foreco.2017.01.031

Shimizu, E. S. C., Pinheiro, H. A., Costa, M. A., \& Santos Filho, B. G. (2011). Aspectos fisiológicos da germinação e da qualidade de plântulas de Schizolobium amazonicum em resposta à escarificação das sementes em lixa e água quente. Revista Árvore, 35(4), 791-800. https://doi.org/10.1590/S0100-676220110 00500004

Silva Neto, P. A., Alvino, F. O., Rayol, B. P., Prata, S. S., \& Esquerdo, L. N. (2007) Métodos para Superação de Dormência em Sementes de Paricá (Schizolobium amazonicum Huber ex. Ducke) (LeguminosaeCaesalpinioideae). Revista Brasileira de Biociências, 5(2), 732-734.

Soares, G. O. S., Leite, R. C., Silva Júnior, G. D., Reis, A. S., Soares, J. L. S., \& Leite, M. R. P. (2017). Methods for overcoming dormancy in teak diaspores. Pesquisa Agropecuária Tropical, 47(4), 384-389. https://doi.org/10.1590/1983-40632017v4749762

Souza, L. A. (2006). Anatomia do fruto e da semente (p. 125). Ponta Grossa: Editora UEPG.

Vidaurre, G. B., Carneiro, A. C. O., Vital, B. R., Santos, R. C., \& Valle, M. L. A. (2012). Propriedades energéticas da madeira e do carvão de Paricá (Schizolobium amazonicum). Revista Árvore, 36(2), 365-371. https://doi.org/10.1590/S0100-67622012000200018

\section{Copyrights}

Copyright for this article is retained by the author(s), with first publication rights granted to the journal.

This is an open-access article distributed under the terms and conditions of the Creative Commons Attribution license (http://creativecommons.org/licenses/by/4.0/). 